\title{
Carbon sequestration potential of nitrogen-fixing tree stands
}

\author{
Mehraj Ahamd Sheikh, Munesh Kumar* and \\ Nagendra Prasad Todaria
}

Sheikh, M.A., Kumar, M., Todaria, N.P. 2015. Carbon sequestration potential of nitrogen-fixing tree stands. - Forestry Studies | Metsanduslikud Uurimused 62, 3947. ISSN 1406-9954. Journal homepage: http://mi.emu.ee/forestry.studies

\begin{abstract}
We compared the $\mathrm{C}$ storage of two nitrogen-fixing trees in mixed and monospecific plantations to investigate the $C$ sequestration potential after 10 years of their establishment. The study was carried out in three types of plantation, Dalbergia sissoo Roxb. ex DC. pure $\left(\mathrm{P}_{1} \mathrm{DS}\right)$, Leucaena leucocephala (Lam.) de Wit pure $\left(\mathrm{P}_{2} \mathrm{LL}\right)$ and mixed plantation of D. sissoo and L. leucocephala ( $\mathrm{P}_{3} \mathrm{DS}$.LL). The results of the study indicated that, $\mathrm{P}_{3}$ DS.LL sequestered $34.30 \pm 0.24 \mathrm{t} \mathrm{yr}^{-1} \mathrm{ha}^{-1} \mathrm{CO}_{2}$ compared to $27.35 \pm 0.19 \mathrm{t} \mathrm{yr}^{-1} \mathrm{ha}^{-1}$ in $P_{1}$ DS and $19.81 \pm 0.44 \mathrm{t} \mathrm{yr}^{-1}$ ha $^{-1}$ in $P_{2}$ LL. Total carbon storage was also maximum in $P_{3}$ DS.LL $\left(93.47 \pm 0.67 \mathrm{t} \mathrm{ha}^{-1}\right)$ followed by $\mathrm{P}_{1} \mathrm{DS}\left(74.54 \pm 0.53 \mathrm{t} \mathrm{ha}^{-1}\right)$ and $\mathrm{P}_{2} \mathrm{LL}(53.98$ $\left.\pm 1.21 \mathrm{tha}^{-1}\right)$. This indicates that $L$. leucocephala has synergetic effect with $D$. sissoo to enhance the carbon sequestration potential when interplanted together. The study revealed that mixed plantation of $\mathrm{N}$-fixer trees have potential to sequester more carbon than same species in monoculture. The study concluded that in reforestation or afforestation program the synergic effect of $\mathrm{N}$-fixer trees can be helpful projects to offset more $\mathrm{C}$ emissions.
\end{abstract}

Keywords: carbon sequestration, Dalbergia sissoo, Leucaena leucocephala, nitrogenfixing, pure, mixed.

Authors' address: Department of Forestry and Natural Resources, HNB Garhwal University, Srinagar Garhwal, Uttarakhand, India, *e-mail: muneshmzu@yahoo.com

\section{Introduction}

Since the beginning of industrial revolution, carbon dioxide concentration in the atmosphere has been rising alarmingly. Prior to the industrial revolution carbon dioxide concentration in the atmosphere was around 270 ppm (Sage, 1995), which has now increased approximate to $398 \mathrm{ppm}$ (ESRl, 2013). If the pace of increase in carbon dioxide concentration remains constant and efforts are not made to reduce it, carbon dioxide concentration in the atmosphere may go up to $800-1000 \mathrm{ppm}$ by the turn of this century (Whipps, 1990). The increasing concentration of greenhouse gases (e.g., $\mathrm{CO}_{2}, \mathrm{CH}_{4}, \mathrm{~N}_{2} \mathrm{O}, \mathrm{O}_{3}$ ) have led to changes in the earth's climate and a warming of the earth's surface although, forestry and afforestation in particular, is regarded as an important means to offset greenhouse gas emissions (Miehle et al., 2006), particularly by reducing the concentration of atmospheric carbon dioxide by increasing carbon sequestration in tree biomass and soils (Turner et al., 2005; Nsabimana et al., 2008). Forest soils are also one of the major carbon sinks on earth, because of their higher organic matter content (Dey, 2005), where soils play a key role in the global carbon budget (Jha et al., 2003; Sheikh et al., 2009) 
Projects that increase the area of plantations have been suggested for inclusion under the clean development mechanism (CDM) as defined in Article 12 of the KyotoProtocol (van Vliet et al., 2003). The UN framework convention on climate change (UNFCCC) followed by the Kyoto Protocol were the first steps taken by the international community in this direction. Afforestation is one of the viable options of $\mathrm{C}$ sequestration in terrestrial ecosystems (IPCC, 1999; Lamb et al., 2005). The potential of $\mathrm{C}$ sequestration through afforestation is estimated, for example, at 3 $\mathrm{Tg} \mathrm{C} \mathrm{yr}{ }^{-1}$ in Norway, 6 TG C yr ${ }^{-1}$ in New Zealand, 9 TG C yr ${ }^{-1}$ in Sweden, 107 TG C

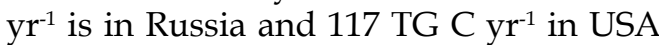
(IPCC, 1999). Forest plantations in 2000 occupied 116 Mha (million hectare) in Asia, 32 Mha in Europe, 28 Mha in America and 8 Mha in Africa (FAO, 2001a). These 187 million ha of tree plantation worldwide represent approximately $5 \%$ of the global forest area (FAO, 2001b; Alvaro \& Florencia, 2006). Proper design and management of plantations can increase biomass accumulation rates making them more effective carbon sinks. The vast majority of tropical tree plantations are monocultures (Binkely et al., 2003). However, mixtures that contain $\mathrm{N}$-fixing species may have an additional potential to increase overall biomass $\mathrm{C}$ sequestration. Estimates of the effects of nitrogen deposition on forest carbon sequestration vary from 0.1 to $2.3 \mathrm{Pg}$ carbon $\mathrm{yr}^{-1}$ (Peterson \& Melillo, 1985; Townsend $e t$ al., 1996; Holland, 1997). If the higher estimates of the effects of nitrogen deposition on forest carbon uptake are accurate, then the terrestrial carbon sink could persist well into the coming century as nitrogen deposition increases. The role that nitrogen deposition plays in determining sink strengths of forests for $\mathrm{CO}_{2}$ depends on where nitrogen inputs to forests ultimately reside (Rastetter et al., 1992; Houghton et al., 1998). If the primary recipients are trees with woody tissues, high carbon-tonitrogen (C:N) mass ratios (of between 200 and > 500) and long turnover times, then the effects of nitrogen deposition on forest carbon uptake are relatively large (Nadelhoffer et al., 1999).

Mixed-species plantations have the potential to improve nutrient cycling, soil fertility (Montagnini, 2000), biomass production (DeBell et al., 1985; Parrotta, 1999) and carbon sequestration (Kaye et al., 2000). Forests with nitrogen-fixing trees typically accumulate more carbon than similar forests without nitrogen-fixing trees (Resh et al., 2002). To understand the role of nitrogen-fixing trees in carbon sequestration, two nitrogen fixing tree species, Dalbergia sissoo Roxb. ex DC. and Leucaena leucocephala (Lam.) de Wit were selected for the study, because both species have wide representation in India. D. sissoo is native to India and is found in most parts of the country whereas L. leucocephala is exotic to India and was introduced in the last century in Andhra Pradesh, Karnataka, Tamil Nadu, Himachal Pradesh and Uttar Pradesh (Lohani, 1979; Luna, 2005), and have almost naturalized in some parts. However, it received attention recently in 1980s, when it was re-introduced in Maharashtra, Gujarat, Punjab, Haryana and West Bengal because of its fast growing nature. Previous researchers (Bi \& Turvey, 1994; Parrotta et al., 1996; Khanna, 1997; Kaye et al., 2000; Resh et al., 2002, Piotto et al., 2003; Petit \& Montagnini, 2004; Bristow et al., 2006) have compared above ground biomass production (and subsequently carbon sequestration potential) between different plantations composed of non $\mathrm{N}$ fixing trees with $\mathrm{N}$-fixing tree species in pure and mixed-plots and their synergetic effect on non $\mathrm{N}$-fixing tree species in mixed plantation. But in the present study we have tried to examine the hypothesis that:

- If both the tree species having nitrogen fixing ability are planted in pure and in mixed stands, will their synergistic effect on each other in mixture results in higher biomass production than pure stands. 
For this study we selected the plantation which was established on land of the Forestry Department, HNB Garhwal University, Srinagar Garhwal, Tehri district of Uttarakhand state. The plantations were not originally established with the view to address the hypothesis but keeping in view the homogeneity of soil and the combination of plantations, where three types of plantations i.e., D. sissoo pure ( $\left.\mathrm{P}_{1} \mathrm{DS}\right)$, L. leucocephala pure $\left(\mathrm{P}_{2} \mathrm{LL}\right)$ and mixed plantation of D. sissoo and L. leucocephala ( $\mathrm{P}_{3} \mathrm{DS}$. LL) already been planted.

\section{Material and Methods}

\section{Study site}

The study area is located in district Tehri Garhwal (lat. 30 3' N, long. 78 48' E) at an elevation of $530 \mathrm{~m}$ asl. Mean temperature ranges from $12.8^{\circ} \mathrm{C}$ in December-January to $32{ }^{\circ} \mathrm{C}$ in April-June. The mean annual precipitation of the area reported of 363 $\mathrm{mm}$. The soils of the area is well drained, stone free and acidic in nature, the area is flat, and of uniform terrain.

\section{Sampling}

For estimating above ground biomass sampling was done by the nested plot design method for each hectare (Hairiah et al., 2001). A nested sampling approach was followed, assessing large diameter trees (with a stem diameter above $30 \mathrm{~cm}$ ) in rectangular plots of $20 \times 100 \mathrm{~m}=2000 \mathrm{~m}^{2}$, smaller trees (stem diameter $5-30 \mathrm{~cm}$ ) in sub plots of $5 \times$ $40 \mathrm{~m}=200 \mathrm{~m}^{2}$.

\section{Volume and biomass estimation}

We used a different approach for volume estimation instead of allometric equations, to avoid the felling of trees. We measured diameter at breast height $(\mathrm{dbh})$ of each tree in the $20 \times 100 \mathrm{~m}$ sample plot as per sampling procedure mentioned above. The diameter at breast height (dbh) was measured with caliper and height with Ravi Multimeter, form factor was calculated with Spiegel Relaskop to find out tree volume (Pressler, 1895; Bitterlich, 1984).

$\mathrm{F}=2 \mathrm{~h}_{1} / 3 \mathrm{~h}$,

where, $\mathrm{F}$ is the form factor, $\mathrm{h}_{1}$ is the height at which diameter is of half $\mathrm{dbh}$ and $\mathrm{h}$ is the total height. Volume (V) was calculated by using the Pressler formula (Pressler, 1895).

$\mathrm{V}=\mathrm{F} \times \mathrm{h} \times \mathrm{g}$,

where $\mathrm{F}$ is the form factor, $\mathrm{h}$ is the total height and $\mathrm{g}$ is the basal area and calculated as:

$$
G=(d b h / 2)^{2}
$$

Bole volume was combined with measured wood density to estimate bole biomass. Branch, twig and foliar biomass were calculated using the fresh mass and water content. We calculated the total number of branches of the sample trees irrespective of size. These branches were categorized on the basis of basal diameter into three groups i.e., $<6 \mathrm{~cm}, 6-10 \mathrm{~cm}$ and $>10 \mathrm{~cm}$. Fresh weight of two branches from each size group was recorded separately. Dry weight of branches was estimated by using following equation (Chidumaya, 1990).

$\mathrm{B}_{\mathrm{dwi}}=\mathrm{B}_{\mathrm{fwi}} / 1+\mathrm{M}_{\mathrm{edbi}}$

where $B_{d w i}$ is the oven dry weight of branches, $\mathrm{B}_{\mathrm{fwi}}$ the fresh / green weight of branches and $M_{\text {edbi }}$ the moisture content of branches on dry weight basis. Total branch biomass (fresh / dry) per sample tree was determined as follows

$\mathrm{B}_{\mathrm{bt}}=\mathrm{n}_{1} \mathrm{bw}_{1}+\mathrm{n}_{2} \mathrm{bw}_{2}+\mathrm{n}_{3} \mathrm{bw}_{3}=\sum_{i=1}^{n} n_{1} \mathrm{bw}_{\mathrm{i}^{\prime}}$

where $B_{b t}$ is the branch biomass per tree, $n_{i}$ is the number of branches in the ith branch group and $I=1,2,3 \ldots$ the branch groups.

Leaves from five branches of individual trees were removed. Five trees per quadrant were taken randomly for observation. 
The leaves were weighed and oven dried separately to a constant weight at $80 \pm 5^{\circ} \mathrm{C}$. The average leaf biomass was then derived by multiplying the average biomass of the leaves per branch with the number of branches in a single tree and then the number of trees in a quadrant (Chidumaya, 1990). The carbon content of vegetation is surprisingly constant across a wide variety of species. Most of the information for carbon estimation described in the literature suggests that carbon constitutes between 45 to 50 percent of dry matter (Chan, 1982; Schlesinger, 1991). We assumed carbon to equal $45 \%$ of tree's biomass. The estimates are based on the assumption of common carbon content per biomass unit as in many other similar studies (Woomer, 1999; Koul \& Panwar, 2008). Total $\mathrm{CO}_{2}$ accumulated per hectare and average rate of $\mathrm{CO}_{2}$ $\left(\mathrm{t} \mathrm{yr}^{-1} \mathrm{ha}^{-1}\right)$ was estimated by combining the carbon storage values with the molecular weight of carbon dioxide. SPSS programme was used to determine the statistical significance for differences in aboveground biomass, and other parameters within the species and between the plantations.

\section{Results}

At ten years of age, tree stands having different tree composition showed a significant difference in total aboveground biomass. Total aboveground biomass accumulation and its allocation to different tree components i.e., bole, branch, twig and foliage is given in Table 1. Tree biomass was highest in $\mathrm{P}_{3}$ DS.LL mixed plantation plot and lowest in $\mathrm{P}_{2} \mathrm{LL}$ monoculture. The biomass was in order of bole $>$ branch $>$ twig $>$ foliage. The biomass of each component in $\mathrm{P}_{2} \mathrm{LL}$ was $88.12 \pm 0.76 \mathrm{t} \mathrm{ha}^{-1}$ for bole followed by $19.17 \pm$ $1.40 \mathrm{t} \mathrm{ha}^{-1}$ in branch, $9.43 \pm 0.97 \mathrm{t} \mathrm{ha}^{-1}$ in twigs and $3.24 \pm 1.19 \mathrm{t} \mathrm{ha}^{-1}$ in foliage. Similar to $\mathrm{P}_{2} \mathrm{LL}$, the biomass of each component in $\mathrm{P}_{1} \mathrm{DS}$ was also recorded in decreasing trend as $126.28 \pm 0.14 \mathrm{tha}^{-1}, 25.10$ $\pm 0.49 \mathrm{t} \mathrm{ha}^{-1}, 9.65 \pm 0.29 \mathrm{t} \mathrm{ha}^{-1}$ and $4.62 \pm$
$0.50 \mathrm{t} \mathrm{ha}^{-1}$ for bole, branch, twig and foliage, respectively. In $P_{3}$ DS.LL similar trend was also recorded in biomass i.e., $157.16 \pm$ $0.66 \mathrm{t} \mathrm{ha}^{-1}$ in bole, $28.19 \pm 0.35 \mathrm{t} \mathrm{ha}^{-1}$ in branch, $11.24 \pm 0.47 \mathrm{tha}^{-1} \mathrm{in}$ twig and $11.13 \pm 0.49 \mathrm{tha}^{-1}$ in foliage. The values of bole biomass were significant $(p<0.05)$ between the plantations. In the present study, we observed that the maximum (207.27 $\left.\pm 1.49 \mathrm{t} \mathrm{ha}^{-1}\right)$ total biomass was in $\mathrm{P}_{3}$ DS.LL followed by $\mathrm{P}_{1} \mathrm{DS}$ (165.55 \pm $\left.1.19 \mathrm{t} \mathrm{ha}^{-1}\right)$ and $\mathrm{P}_{2} \mathrm{LL}\left(119.96 \pm 2.70 \mathrm{t} \mathrm{ha}^{-1}\right)$.

Above ground tree biomass in each plantation was calculated separately for different components i.e., bole, branch, twig and foliage. In $\mathrm{P}_{1} \mathrm{DS}$ the biomass allocation for different components was 76\%, 15\%,6\% and $3 \%$ for bole, branch, twig and foliage respectively. In $\mathrm{P}_{2} \mathrm{LL}$ bole contributed 73\% biomass in comparison to 16\% (branch), $8 \%$ (twig) and 3\% (foliage). Similarly in $\mathrm{P}_{3} \mathrm{DS}$. LL the maximum biomass was stored in bole $(76 \%)$ followed by branch $(14 \%)$, twig (5\%) and foliage (5\%) (Figure 1).

Converting biomass into carbon stock revealed significant difference in total $\mathrm{C}$ stock $(p<0.05)$ between the plantations. The carbon stock stored and total atmospheric carbon dioxide sequestered by different components during the ten year age of different plantations is given in Table 1. The carbon stock in each component of $\mathrm{P}_{2} \mathrm{LL}$ was $39.65 \pm 0.34,8.62 \pm 0.63,4.24 \pm 0.43$ and $1.45 \pm 0.53 \mathrm{t} \mathrm{ha}^{-1}$ in bole, branch, twig and foliage respectively. Similarly in $P_{1} D S$ and $\mathrm{P}_{3}$ DS.LL the $\mathrm{C}$ stock was found in reducing order from bole $>$ branch $>$ twig $>$ foliage with the values of $56.82 \pm 0.06,11.29 \pm 0.22$, $4.34 \pm 0.13$ and $2.08 \pm 0.22$ in $P_{1} L L$ and $70.72 \pm 0.30,12.68 \pm 0.16,5.05 \pm 0.21$ and $5.00 \pm 0.22$ in $P_{3}$ DS.LL., respectively. The maximum carbon stock stored was again reported in $P_{3}$ DS.LL $93.47 \pm 0.67 \mathrm{t} \mathrm{ha}^{-1}$ followed by $\mathrm{P}_{1} \mathrm{DS}\left(74.54 \pm 0.53 \mathrm{tha}^{-1}\right)$ and $\mathrm{P}_{2} \mathrm{LL}$ $\left(53.98 \pm 1.21 \mathrm{t} \mathrm{ha}^{-1}\right)$.

The monoculture plantations $\mathrm{P}_{1} \mathrm{DS}$ and $\mathrm{P}_{2} \mathrm{LL}$ accumulated atmospheric $\mathrm{CO}_{2}$ with an annual rate of $27.35 \pm 0.19 \mathrm{t} \mathrm{ha}^{-1}$ and $19.81 \pm 0.44 \mathrm{t} \mathrm{ha}^{-1}$ (Table 2). However, in $\mathrm{P}_{3}$ DS.LL, the accumulation of $\mathrm{CO}_{2}$ from at- 


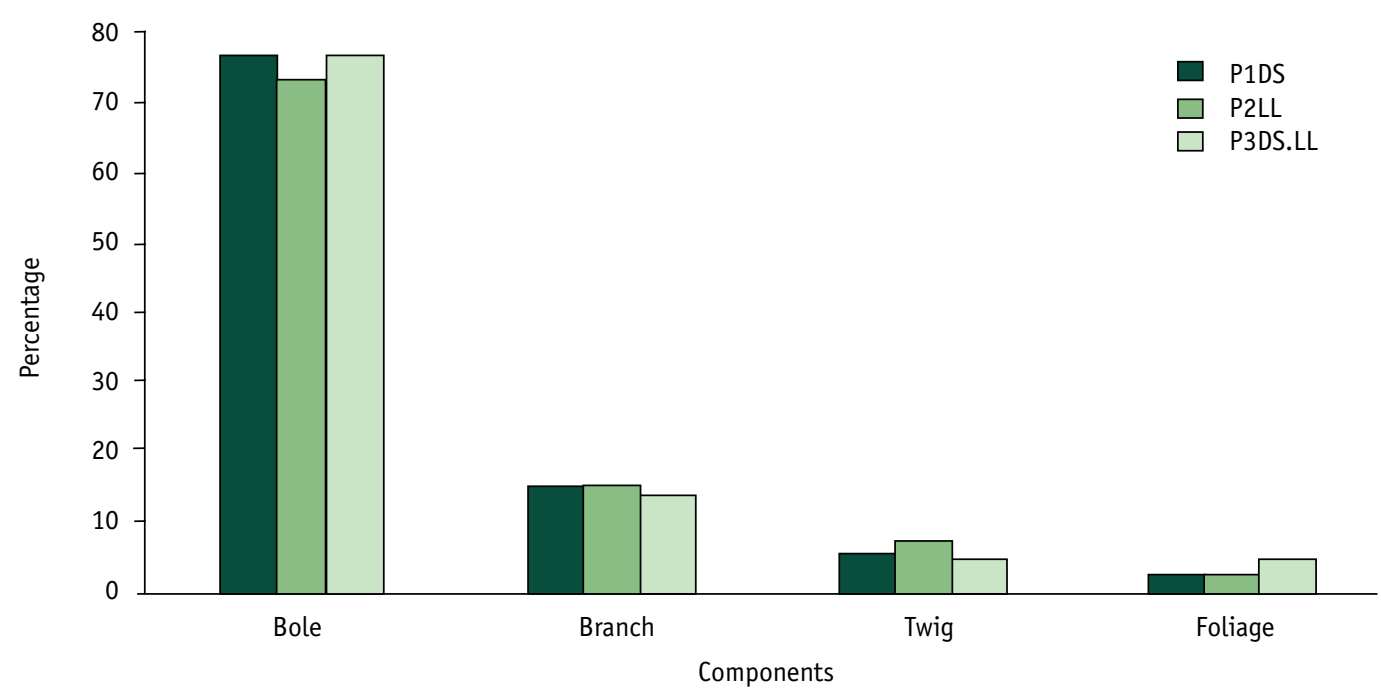

Figure 1. Percentage of biomass accumulation and its allocation to different tree components.

Table 1. Component wise biomass $\mathrm{t} \mathrm{ha}^{-1}$ and carbon $\mathrm{t} \mathrm{ha}^{-1}$ in different plantations after 10 years.

\begin{tabular}{llcccccccccc}
\hline Parameter Component & \multicolumn{9}{c}{ Plantation } \\
\cline { 3 - 12 } & & \multicolumn{9}{c}{ P $_{1}$ DS } & \multicolumn{3}{c}{ P $_{2}$ LL } & \multicolumn{3}{c}{ P $_{3}$ DS.LL } \\
\cline { 2 - 12 } & & Mean & SE & Sig & Mean & SE & Sig & Mean & SE & Sig \\
\hline Biomass & Bole & 126.28 & 0.14 & (b) B & 88.12 & 0.76 & (b) C & 157.16 & 0.66 & (b) A \\
& Branch & 25.10 & 0.49 & (c) B & 19.17 & 1.40 & (c) B & 28.19 & 0.35 & (c) A \\
& Twig & 9.65 & 0.29 & (d) A & 9.43 & 0.97 & (d) A & 11.24 & 0.47 & (d) A \\
& Foliage & 4.62 & 0.50 & (e) B & 3.24 & 1.19 & (d) B & 11.13 & 0.49 & (d) A \\
& Total & 165.66 & 1.19 & (a) B & 119.96 & 2.70 & (a) C & 207.72 & 1.49 & (a) A \\
\hline Carbon & Bole & 56.82 & 0.06 & (b) B & 39.65 & 0.34 & (b) C & 70.72 & 0.30 & (b) A \\
& Branch & 11.29 & 0.22 & (c) B & 8.62 & 0.63 & (c) C & 12.68 & 0.16 & (c) A \\
& Twig & 4.34 & 0.13 & (d) A & 4.24 & 0.43 & (d) B & 5.05 & 0.21 & (d) A \\
& Foliage & 2.08 & 0.22 & (e) B & 1.45 & 0.53 & (e) C & 5.00 & 0.22 & (d) A \\
& Total & 74.54 & 0.53 & (a) B & 53.98 & 1.21 & (a) C & 93.47 & 0.67 & (a) A \\
\hline
\end{tabular}

Difference within a species (a) and between the species (A) for a given issue are statistically significant $(p<0.05)$ when means are followed by different letters. 


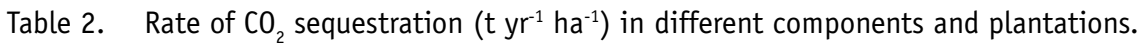

\begin{tabular}{llccccccccc}
\hline Parameter & Component & \multicolumn{9}{c}{ Plantation } \\
\cline { 3 - 12 } & & \multicolumn{3}{c}{$\mathrm{P}_{1}$ DS } & \multicolumn{3}{c}{$\mathrm{P}_{2}$ LL } & \multicolumn{3}{c}{$\mathrm{P}_{3}$ DS.LL } \\
\cline { 3 - 12 } & & Mean & SE & Sig & Mean & SE & Sig & Mean & SE & Sig \\
\hline $\mathrm{CO}_{2}$ & Bole & 20.85 & 0.02 & (b) B & 14.55 & 0.12 & (b) C & 25.95 & 0.11 & (b) A \\
$\left(\mathrm{t} \mathrm{yr}^{-1} \mathrm{ha}^{-1}\right)$ & Branch & 4.14 & 0.08 & (c) B & 3.16 & 0.23 & (c) C & 4.65 & 0.05 & (c) A \\
& Twig & 1.59 & 0.04 & (d) A & 1.55 & 0.15 & (d) A & 1.85 & 0.07 & (d) A \\
& Foliage & 0.76 & 0.08 & (e) B & 0.53 & 0.19 & (e) C & 1.83 & 0.08 & (d) A \\
& Total & 27.35 & 0.19 & (a) B & 19.81 & 0.44 & (a) C & 34.30 & 0.24 & (a) A \\
\hline
\end{tabular}

Difference within a species (a) and between the species (A) for a given issue are statistically significant $(p<0.05)$ when means are followed by different letters.

mosphere was maximum that of monocultures, with an annual rate of $34.30 \pm 0.24 \mathrm{t}$ ha $^{-1}$ (Table 2).

\section{Discussion}

In the present study we observed that maximum above ground biomass and carbon stock was present in mixed plantation $\mathrm{P}_{3}$ DS.LL followed by $\mathrm{P}_{1} \mathrm{DS}$ and $\mathrm{P}_{2}$ LL. $\mathrm{P}_{1} \mathrm{DS}$ stored more carbon than $\mathrm{P}_{2} \mathrm{LL}$. However, the $\mathrm{P}_{3}$ DS.LL mixed stand stored $18 \%$ more carbon than $\mathrm{P}_{2} \mathrm{LL}$ and $9 \%$ more than $\mathrm{P}_{1} \mathrm{DS}$. The maximum carbon stock in $P_{3}$ DS.LL might be due to the high nitrogen fixing capacities of L. leucocephala and its combined effect with D. sissoo. Kaye et al. (2000) observed that carbon sequestration was significantly boosted when Eucalyptus plantations included nitrogen-fixing trees. Resh et al. (2002) also found that the forests with nitrogen-fixing trees typically accumulate more carbon in soils than similar forests without N-fixing trees. However, the present study showed that the mixture of nitrogen-fixing trees act synergistically too. Nitrogen-fixing tree species have larger effects on forest soils than other species, and these effects include consistent increases in soil organic matter and carbon. Across 19 case studies, an increase in $1 \mathrm{~g} \mathrm{~N}$ was associated with an increase of 12 to $15 \mathrm{~g} \mathrm{C}$ (Binkley \& Menyailo, 2005). Nitrogen, fix- ing trees change soils more rapidly than other species. The changes in soil nitrogen begin with the fixation of $\mathrm{N}$ by symbiotic bacteria in root nodules and the incorporation of this $\mathrm{N}$ into tree tissue (Binkley \& Menyailo, 2005).

It is interesting to note that foliage biomass nearly doubled in the mixed species $\mathrm{P}_{3}$ DS.LL compared to the single species stands $5.4 \%$ vs $2.87 \%$ and $2.8 \%$. This greater investment in assimilating leaf area may explain the increased rate of carbon sequestration in $\mathrm{P}_{3} \mathrm{DS}$.LL. Increased $\mathrm{N}$ availability may also increase leaf area, which increases light capture and canopy photosynthesis, and hence gross primary production (Landsberg, 1997). For example Cromer et al. (1993) and Smethurst et al. (2003) found that $\mathrm{N}$ and $\mathrm{P}$ fertiliser increased leaf area and biomass productions in plantations of Eucalyptus grandis W. Hill ex Maiden and E. nitens ( $\mathrm{H}$. Deane et Maiden) Maiden, respectively. However, increases in leaf area in response to fertiliser may also be associated with changes in the allocation of $\mathrm{C}$ from belowground to aboveground growth (Cannell, 1985). Increase in nutrient availability can shift allocation of $\mathrm{C}$ from roots and mycorrhizae (for nutrient uptake) to aboveground plant parts, to increase the capture of light and $\mathrm{CO}_{2}$ (Cannell, 1985; Raich, 1998; McConnaughay \& Coleman, 1999). However, few studies have examined whether increase 
in aboveground growth associated with a higher nutrient availability results from an increase in total productivity (both aboveand belowground) or a shift in biomass partitioning, or both (Ryan et al., 1996; Keith et al., 1997). Furthermore, the results of such studies have been variable, documenting increase, decrease and no change in belowground $\mathrm{C}$ fluxes with increasing nutrient supply (Haynes \& Gower, 1995; Ryan et al., 1996; Keith et al., 1997; Raich, 1998; Zak \& Pregitzer, 1998; Pongracic, 2001; Giardina \& Ryan, 2002; Giardina et al., 2003).

Changes in the composition of tree species which result from land use or climate change may have important feedbacks to terrestrial carbon sequestration (Kaye et al., 2000). Results from the previous research have indicated the capacity of mixed-species stands to produce relatively high levels of biomass (Montagnini \& Porras, 1998). The idea of tree plantations as a sink for carbon dioxide has gained momentum over the last decade. The use of tree plantations can be multifunctional; soil rehabilitation, direct economic rewards and carbon sequestration. Pure and mixed-species plantations at La Selva have shown that mixed plantations grow well, with productivities either similar or larger than the same species grown in pure plantations (Piotto et al., 2003; Petit \& Montagnini, 2004). As a consequence, mixed plantations also accumulate more aboveground biomass and sequester carbon at high rates as compared to pure plantations (Montagnini \& Porras, 1998; Stanley \& Montagnini, 1999). The mixed plantations also contribute to recovery of soil fertility (Montagnini \& Porras, 1998). Mixed-species plantations have the potential for out producing monocultures, but actual yields depend on soil, silviculture, and species (Binkley et al., 2003).

\section{Conclusion}

Earlier studies have revealed the synergistic effect of nitrogen fixing trees for non- nitrogen fixing trees species. Similar increase in plant productivity and soil C was seen in the current study when two $\mathrm{N}$-fixing tree species were intermixed in a single stand. Today, the earth's forests are shrinking; we are loosing a major $\mathrm{CO}_{2}$ sink. Hence the goal is to expand the earth's tree cover, growing more trees to soak up $\mathrm{CO}_{2}$

The study concluded that mixed plantation of N-fixing tree species has potential to sequester more carbon and have higher synergetic effect to enhance the carbon sequestration potential. The mean $\mathrm{CO}_{2}$ sequestration rate increases significantly in mixed plantation than in monoculture plantations.

\section{References}

Alvaro. R.B., Florencia, M. 2006. Growth, productivity, aboveground biomass and carbon sequestration of pure and mixed native tree plantations in the Caribbean lowlands of Costa Rica. - Forest Ecology and Management, 232, 168-178.

Bi, H., Turvey. N.D. 1994. Interspecific competition between seedlings of Pinus radiata, Eucalyptus regnans and Acacia melanoxylon. - Australian Journal of Botany, 42, 61-70.

Binkley, D, Menyailo, O. (eds.). 2005. Tree species effects on soils: implication for global change. NATO Science Series, IV: Earth and Environmental Sciences, 55, 155-164.

Binkley, D., Senock, R, Bird, S., Cole. T.G. 2003. Twenty years of stand development in pure and mixed stands of Eucalyptus saligna and nitrogenfixing $\mathrm{Fa}$ caltaria moluccana. - Forest Ecology and Management, 182, 93-102.

Bitterlich, W. 1984. The relascope idea: relative measurements in forestry. Commonwealth Agricultural Bureaux, Farnham Royal, Slough, UK.

Bristow, M., Vanclaym J., Brooks, L., Hunt, M. 2006. Growth and species interactions of Eucalyptus pellita in a mixed and monoculture plantation in the humid tropics of north Queensland. - Forest Ecology and Management, 233(2-3), 285-294.

Cannell, M.G.R. 1985. Dry matter partitioning in tree crops. - Cannell, M.G.R., Jackson, J.E. (eds.). Attributes of trees as crop plants. Institute of Terrestrial Ecology, Abbots Ripton, Huntingdon, Essex, UK, 160-193.

Chan, Y.H. 1982. Storage and release of organic carbon in peninsular Malaysia. - International Journal of Environmental Studies, 18, 211-222. 
Chidumaya, E.N. 1990. Aboveground woody biomass structure and productivity in a Zambezian woodland. - Forest Ecology and Management, 36, 33-46.

Cromer, R.N., Cameron, D.M., Rance, S.J., Ryan, P.A., Brown, M. 1993. Response to nutrients in Eucalyptus grandis. 1. Biomass accumulation. - Forest Ecology and Management, 62, 211-230.

DeBell, D.S., Whitesell, C.D., Schubert, T.H. 1985. Mixed plantations of Eucalyptus and leguminous trees enhance biomass production. USDA Forest Service Research Paper PSW-175.

Dey, S.K. 2005. A preliminary estimation of carbon stock sequestrated through rubber (Hevea brasiliensis) plantation in North Eastern regional of India. - Indian Forester, 31(11), 1429-1435.

ESRl. 2013. Earth Systems Research Laboratory. National Oceanic and Atmospheric Administration (NOAA). [WWW document]. - URL http:// WWW.CO2NOW.org [Accessed 30 August 2015].

FAO. 2001a. Global Forest Resources Assessment 2000. Main Report. Forestry Paper No. 140, FAO, Rome, p. 479

FAO. 2001b. Food and Agriculture Organization. State of the World's Forests 2001, Rome, Italy.

Giardina, C.P., Ryan, M.G. 2002. Total belowground carbon allocation in a fast-growing Eucalyptus plantation estimated using a carbon balance approach. - Ecosystems, 5, 487-499.

Giardina, C.P., Ryan, M.G., Binkley, D., Fownes. J.H. 2003. Primary production and carbon allocation in relation to nutrient supply in a tropical experimental forest. - Global Change Biology, 9, 1438-1450.

Hairiah, K., Sitompul, S.M., van Noordwijk, M., Palm, C. 2001. Methodology for sampling carbon stocks above and below ground. ASB Lecture Note 4B. International Centre for Research in Agroforestry, Indonesia. [WWW document]. - URL http:/ / www.asb.cgiar.org [Accessed 30 August 2015].

Haynes, B.E., Gower, S.T. 1995. Belowground carbon allocation in unfertilized and fertilized red pine plantations in northern Wisconsin. - Tree Physiology, 15, 317-325.

Holland, E.A. 1997. Variations in the predicted spatial distribution of atmospheric nitrogen deposition and their impact on carbon uptake by terrestrial ecosystems. - Journal of Geophysical Research, 102, 15849-15866.

Houghton, R.A., Davidson, E.A., Woodwell, G.M. 1998. Missing sinks, feedbacks, and understanding the role of terrestrial ecosystems in the global carbon balance. - Global Biogeochemical Cycles, $12,25-34$

IPCC. 1999. Land use, land use change and forestry. Intergovernmental Panel of Climate Change. Cambidge University Press, Cambridge, UK.

Jha, M.N., Gupta. M.K., Saxena. A., Kumar. R. 2003. Soil organic carbon store in different forests in India. - Indian Forester, 129(6), 714-724.
Kaye, J.P., Resh, S.C., Kaye, M.W., Chimner, R.A. 2000. Nutrient and carbon dynamics in a replacement series of Eucalyptus and Albizia trees. - Ecology, 81(12), 3267-3273.

Keith, H., Raison, R.J., Jacobsen, K.L. 1997. Allocation of carbon in a mature eucalypt forest and some effects of soil phosphorus availability. - Plant Soil, 196, 81-99.

Khanna, P.K. 1997. Comparison of growth and nutrition of young monocultures and mixed stands of Eucalyptus globulus and Acacia mearnsii. - Forest Ecology and Management, 94, 105-113.

Koul, D.N., Panwar, P. 2008. Prioritizing land-management options for carbon sequestration potential. - Current Science, 95, 658-663.

Lamb, D., Erskine, P.D., Parrotta, J.A. 2005. Restoration of degraded tropical forest landscape. - Science, 310, 1628-1632.

Landsberg, J.J. 1997. The biophysical environment. Nambiar, E.K.S., Brown, A.G. (eds.). Management of soil, nutrients and water in tropical plantation forests. Australian Centre 20 for International Agricultural Research, Canberra, 65-96.

Lohani, D.N. 1979. Preliminary trials with high yielding varieties of L. leucocephala. - Indian Forester, 3, 199-202.

Luna, R.K. 2005. Plantation trees. International Book Distributors, Dehrudun. 975 pp.

McConnaughay, K.D.M., Coleman, J.S. 1999. Biomass allocation in plants: ontogeny or optimality? A test along three resource gradients. - Ecology, 80, 2581-2593.

Miehle, P., Livesley, S.J., Feikema, P.M., Li, C., Arndt, S.K. 2006. Assessing productivity and carbon sequestration capacity of Eucalyptus globulus plantation using the process model Forest-DNDC: calibration and validation. - Ecological Modelling, 192, 83-94.

Montagnini, F. 2000. Accumulation in above-ground biomass and soil storage of mineral nutrients in pure and mixed plantations in a humid tropical lowland. - Forest Ecology and Management, 134, 257-270.

Montagnini, F., Porras. C. 1998. Evaluating the role of plantations as carbon sinks: an example of an integrative approach from the humid tropics. - Environmental Management, 22(3), 459-470.

Nadelhoffer, K.J., Emmett, B.A., Gundersen, P., Kjonass, O.J., Koopmans, C.J., Schleppi, P., Tietema, A., Wright, R.F. 1999. Nitrogen deposition makes a minor contribution to carbon sequestration in temperate forests. - Nature, 398, 145-148.

Nsabimana, D., Klemedtson, L., Kaplin, B.A., Wallin, G. 2008. Soil carbon and nutrient accumulation under forest plantations in southern Rwanda. African Journal of Environmental Science and Technology, 2(6), 142-149.

Parrotta, J.A. 1999. Productivity, nutrient cycling, and succession in single- and mixed-species plantations of Casuarina equisetifolia, Eucalyptus robusta, 
and Leucaena leucocephala in Puerto Rico. - Forest Ecology and Management, 124, 45-77.

Parrotta, J.A., Baker, D.D., Fried, M. 1996. Changes in dinitrogen fixation in maturing stands of Casuarina equisetifolia and Leucaena leucocephala. - Canadian Journal of Forest Research, 26, 1684-1691.

Peterson, B.J., Melillo, J.M. 1985. The potential storage of carbon caused by eutrophication of the biosphere. - Tellus, 37B, 117-127.

Petit, B., Montagnini, F. 2004. Growth equation and rotation age of ten native tree species in mixed and pure plantations in the humid neotropics. Forest Ecology and Management, 199, 243-257.

Piotto, D., Montagnini, F., Ugalde, L., Kanninen, M. 2003. Growth and effects plantations. - Forest Ecology and Management, 50, 31-41.

Pongracic, S. 2001. Influence of irrigation and fertilization on the belowground carbon allocation in a pine plantation. PhD thesis. The University of New South Wales, Sydney.

Pressler, M. 1895. The law of education in Leipzig. (Das Gesetz der Stambildung Leipzig). 153 pp. (In German).

Raich, J.W. 1998. Aboveground productivity and soil respiration in three Hawaiian rain forests. - Forest Ecology and Management, 107, 309-318.

Rastetter, E.B., McKane, R.B., Shaver, G.R., Melillo, J.M. 1992. Changes in C storage by terrestrial ecosystems: how $\mathrm{C}-\mathrm{N}$ interactions restrict responses to $\mathrm{CO}_{2}$ and temperature. - Water, Air and Soil Pollution, 64, 327-344.

Resh, S.C., Binkley, D., Parrotta, J.A. 2002. Greater soil carbon sequestration under nitrogen-fixing trees compared with Eucalyptus species. - Ecosystems, 5, 217-231.

Ryan, M.G., Hubbard, R.M., Pongracic, S., Raison, R.J., McMurtrie, R.E. 1996. Foliage, fine-root, woody-tissue and stand respiration in Pinus radiata in relation to nitrogen status. - Tree Physiology, 16, 333-343.

Sage, R.F. 1995. Was low atmospheric $\mathrm{CO}_{2}$ during the Pleistocene a limiting factor for the origin of agriculture. - Global Change Biology, 1, 93-106.
Schlesinger, W.H. 1991. Biogeochemistry: an analysis of global change. Academic Press, New York, USA.

Sheikh, M.A., Kumar, M., Bussmann, R.W. 2009. Altitudinal variation in soil organic carbon stock in coniferous subtropical and broadleaf temperate forests in Garhwal Himalaya Carbon Balance Management 2009, 4:6. DOI: 10.1186/1750-06804-6.

Smethurst, P., Baillie, C., Cherry, M., Holz, G. 2003. Fertilizer effects on LAI and growth of four Eucalyptus nitens plantations. - Forest Ecology and Management, 176, 531-542.

Stanley, W.G., Montagnini, F. 1999. Biomass and nutrient accumulation in pure and mixed plantations of indigenous tree species grown on poor soils in the tree species in mixed and pure plantations in the humid neotropics. - Forest Ecology and Management, 199, 243-257.

Townsend, A., Braswell, B.H., Holland, E.A. 1996. Spatial and temporal patterns in terrestrial carbon storage due to deposition of anthropogenic nitrogen. - Ecological Applications, 6, 806-814.

Turner, J., Lambert, M.J., Johnson, D.W. 2005. Experience with patterns of soil carbon resulting from forest plantation establishment in eastern Australia. - Forest Ecology Management, 220, 259-269.

van Vliet, O.P.R., Faaij, A.P.C., Dieperink, C. 2003. Forestry projects under the clean development mechanism? Modelling of the uncertainties in carbon mitigation and related costs of plantation forestry projects. - Climatic Change, 61, 123-156.

Whipps, J.M. 1990. Carbon Eonomy. - Lynch, J.M. (ed.). The Rhizosphere. Wiley, New York, 59-97.

Woomer, P.L. 1999. Impact of cultivation of carbon fluxes in woody savannas of southern Africa. Water, Air and Soil Pollution, 70, 403-412.

Zak, D.R., Pregitzer, K.S. 1998. Integration of ecophysiological and biogeochemical approaches to ecosystem dynamics. - Pace, M.L., Groffman, P.M. (eds.). Successes, limitations and frontiers in ecosystem science. Springer, New York, 372-403. 